Research Paper

\title{
TT genotype of rs2941484 in the human HNF4G gene is associated with hyperuricemia in Chinese Han men
}

\author{
Bang-Dang Chen ${ }^{1,2, *}$, Xiao-Cui Chen ${ }^{1,2, *}$, Shuo Pan ${ }^{3, *}$, Yi-Ning Yang ${ }^{1,2}$, Chun-Hui He ${ }^{2}$, Fen \\ Liu $^{1,2}$, Xiang $\mathrm{Ma}^{1,2}$, Min-Tao Gai ${ }^{1,2}$, Yi-Tong $\mathrm{Ma}^{1,2}$ \\ ${ }^{1}$ Xinjiang Key Laboratory of Cardiovascular Disease, Clinical Medical Research Institute of First Affiliated Hospital of Xinjiang \\ Medical University, Urumqi, China \\ ${ }^{2}$ Department of Cardiology, First Affiliated Hospital of Xinjiang Medical University, Urumqi, China \\ ${ }^{3}$ First Department of Cardiology, People's Hospital of Shaanxi Province, Xi'an, China \\ *These authors contributed equally to this work
}

Correspondence to: Yi-Tong Ma, email: myt-xj@163.com

Keywords: hyperuricemia, HNF4G, single nucleotide polymorphism, genetic, case-control association study

Received: January 23, $2017 \quad$ Accepted: February 20, $2017 \quad$ Published: March 02, 2017

Copyright: Chen et al. This is an open-access article distributed under the terms of the Creative Commons Attribution License (CC-BY), which permits unrestricted use, distribution, and reproduction in any medium, provided the original author and source are credited.

\section{ABSTRACT}

The aim of the study is to investigate the association between the human hepatocyte nuclear factor 4 gamma (HNF4G) gene and hyperuricemia in Chinese Han population. A total of $\mathbf{4 1 4}$ hyperuricemia patients and $\mathbf{4 0 6}$ gender and age-matched normouricemic controls were enrolled. Four single nucleotide polymorphisms were genotyped as genetic markers for the human HNF4G gene (rs2977939, rs1805098, rs2941484, rs4735692). Data were analyzed for two separate groups: men and women. For rs2941484, the genotype distribution frequency in hyperuricemic subjects and was significantly different from that in normouricemic controls in men $(P=0.038)$. Meanwhile, in recessive model of rs2941484, the distribution frequency of TT genotype and $\mathrm{CC}+\mathrm{CT}$ genotypes also differed significantly between the hyperuricemia men and normouricemic men $(P=\mathbf{0 . 0 1 1})$. For the other 3 SNPs in both men and women, there was no difference in the genotype and allele and distribution frequency between the hyperuricemia patients and normouricemic controls. In men, after adjustments for BMI, SBP, DBP, fasting glucose, total cholesterol, triglycerides, low density lipoprotein cholesterol and creatinine, the men with the TT genotype of rs2941484 were found to have significantly higher probability of suffering from hyperuricemia than the ones with CT and CC genotypes (OR $=2.170, P<0.001)$. Therefore, TT genotype of rs2941484 in the human HNF4G gene might be a gender-specific genetic marker for hyperuricemia in Chinese Han men.

\section{INTRODUCTION}

Uric acid is a final breakdown product of purine oxidation in humans. Elevated concentrations of serum uric acid, which is named as hyperuricemia, can cause gout [1-2]. Gout is the most prevalent inflammatory arthritis in US, with an estimated 8.3 million adults having had at least one of the extremely painful attacks in 2007-2008 [3]. Via reviewing the epidemiological surveys conducted in China, the pooled prevalence of hyperuricemia and gout was $13.3 \%$ and $1.1 \%$, respectively [4]. It is especially common in the elderly population, one quarter of Chinese population had hyperuricemia according to a recent cross-sectional study of 3978 men aged 40-74 yrs living in Shanghai, China [5].
The increasing of hyperuricemia and gout prevalence is partly owing to aging, dietary and lifestyle factors, and rising levels of obesity and insulin resistance [6-9]. The heritability of serum uric acid concentrations is estimated at $40-70 \%$ [10-12], which justifies the search for its genetic determinants. An recent genome-wide association study (GWAS) combined data from > 140,000 individuals of European ancestry within the Global Urate Genetics Consortium (GUGC) [13], they reported that single nucleotide polymorphisms (SNPs) near HNF4G was found to be associated with uric acid concentrations $(P=4.4 \times 10-17)$.

Hepatocyte nuclear factor 4 gamma (HNF4G) gene in human is one of the two isoforms of human HNF4 gene, while the other isoform is hepatocyte nuclear factor 
4 alpha (HNF4A). The HNF4G was originally identified in rat liver nuclear extracts as a protein binding to a DNA element of the transthyretin promoter [14]. Previous study also revealed that HNF4 is an orphan member of the nuclear receptor superfamily with a DNA binding domain and a putative ligand binding domain [15]. Binding sites for HNF4G have been found in the regulatory regions of many genes expressed in the liver and kidney [16]. Since the blood uric acid concentrations are determined by a balance between uric acid production in the liver and its disposal via the kidney and gut, we hypothesized that HNF4G may play an important role in uric acid heritability features.

Therefore, the objective of this study was to assess the genetic associations of $H N F 4 G$ polymorphisms and hyperuricemia in Chinese Han population in Xinjiang.

\section{RESULTS}

Table 1 shows the clinical characteristics of the study participants. The age and gender distribution frequency between the hyperuricemia patients and normouricemic controls showed no significant difference in both men and women. For both men and women, BMI, WC, SBP, total cholesterol, triglycerides, LDL-C, fasting glucose, creatinine, urea nitrogen and uric acid were significantly higher for the hyperuricemia patients as compared to the normouricemic control subjects. DBP was significantly higher for the hyperuricemia men as compared to the normouricemic control men, however, the trend was not observed in women.

Table 2 shows the distribution frequency of the genotypes and alleles for the four SNPs. The genotype distribution frequency for each of the SNPs was in good agreement with the predicted Hardy-Weinberg equilibrium values (data not shown). For rs2941484 (SNP3), the genotype distribution frequency in hyperuricemic subjects and was significantly different from that in normouricemic controls in men $(P=0.038)$. Meanwhile, in recessive model of rs2941484, the distribution frequency of TT genotype and $\mathrm{CC}+\mathrm{CT}$ genotypes also showed the significant difference between the hyperuricemia men and normouricemic men $(P=0.011)$. However, the same trend was not noticed in women. For the other 3 SNPs selected for present study, there was no difference in the genotype and allele and distribution frequency between the hyperuricemia patients and normouricemic controls.

Since the TT genotype distribution frequency of rs2941484 was significantly higher in hyperuricemic men as compared to the normouricemic control men, we may identify TT genotype as a risk factor for hyperuricemia in Chinese Han men. Therefore, the logistic regression analysis was performed using TT genotype of rs2941484 and each of the risk factors associated with the hyperuricemia (Table 3). In men, after adjustments for BMI, SBP, DBP, fasting glucose, total cholesterol, triglycerides, LDL-C and creatinine, the men with the TT genotype of rs2941484 were found to have significantly higher probability of suffering from hyperuricemia than the ones with $\mathrm{CT}$ and $\mathrm{CC}$ genotypes $(O R=2.170, P<0.001)$. Meanwhile, we also found BMI, fasting glucose, total cholesterol, LDL-C, creatinine were associated with hyperuricemia in Chinese Han men (all $P<0.05$ ).

\section{DISCUSSION}

Accumulating evidence suggests that hyperuricemia is one of the important factors that may significantly contribute to the development and progression of the cardiorenal and metabolic disorders [17, 18]. Elevated levels of uric acid were found to be associated with inflammation, oxidative stress, insulin resistance, dysglycemia, endothelial dysfunction, vascular, renal and cardiac stiffness, cardiac diastolic dysfunction, renal hyperfiltration and proteinuria [19-21]. Studies of twins and families have shown the inheritance for both hyperuricaemia and excretion of urate via the kidneys [22]. In one study in twins, the heritability of the renal clearance of urate was $60 \%$ to $87 \%$ [23]. Other studies have shown that serum urate levels have substantial heritable traits (40\%) [24]. Over the past decade, GWAS, replication studies and meta-analyses have led to a remarkable increase in our knowledge of common genetic variants that predispose to hyperuricaemia and gout. An recent genome-wide association studies (GWAS) combined data from $>140,000$ individuals of European ancestry within the Global Urate Genetics Consortium (GUGC) [13], they reported 18 new loci associated with serum urate concentrations. Among them, rs2941484 of $H N F 4 G$ was found to be associated with uric acid concentrations with the effect value was $0.044(P=4.4 \times 10-17)$. However, the OR value for the gout is 1.04 , the difference was not significant $(P=1.7 \times 10-1)$.

HNF4 was first identified as a DNA binding activity in rat liver nuclear extracts. With protein purification technique, the cDNA of rat HNF4 was cloned and HNF4 was found to be an orphan member of the nuclear receptor superfamily [14, 26]. Binding sites for HNF4 were identified in many tissues, the expressed genes and the proteins were found to be essential for early embryonic development in the mouse [26]. HNF4G gene in human is one of the two isoforms of human HNF4 gene, while the other isoform is $H N F 4 A$. HNF4G is a member of the HNF4 orphan subfamily [27]. It can be expressed in the pancreas, kidney, small intestine and testis, however, it can not be expressed in the human liver [14]. The gene regulation effected by $H N F 4 G$ has been reported to occur in coordination with $H N F 4 A$ [28-30].

In this present study, the genotype frequency of rs2941484 showed significantly difference between the hyperuricemia men and normouricemic men, the men with the TT genotype of rs2941484 were found to 
Table 1: Characteristics of control subjects and patients with hyperuricemia

\begin{tabular}{|c|c|c|c|c|}
\hline & \multicolumn{2}{|c|}{ Men } & \multicolumn{2}{|c|}{ Women } \\
\hline & $\begin{array}{c}\text { Normouricemic } \\
\text { controls }\end{array}$ & $\begin{array}{c}\text { Hyperuricemic } \\
\text { subjects }\end{array}$ & $\begin{array}{l}\text { Normouricemic } \\
\text { controls }\end{array}$ & $\begin{array}{c}\text { Hyperuricemic } \\
\text { subjects }\end{array}$ \\
\hline Number of subjects & 243 & 250 & 163 & 164 \\
\hline Age (years) & $55.5 \pm 8.8$ & $55.6 \pm 12.4$ & $58.5 \pm 14.8$ & $58.4 \pm 12.6$ \\
\hline $\operatorname{BMI}\left(\mathrm{kg} / \mathrm{m}^{2}\right)$ & $22.2 \pm 4.7$ & $24.6 \pm 4.4^{*}$ & $21.5 \pm 3.5$ & $23.4 \pm 5.1 *$ \\
\hline $\mathrm{WC}(\mathrm{cm})$ & $76.2 \pm 14.2$ & $80.5 \pm 12.5^{*}$ & $71.3 \pm 10.1$ & $74.3 \pm 12.8^{*}$ \\
\hline $\mathrm{SBP}(\mathrm{mmHg})$ & $126.7 \pm 21.1$ & $133.3 \pm 18.8^{*}$ & $121.3 \pm 17.8$ & $127.6 \pm 24.2^{*}$ \\
\hline DBP $(\mathrm{mmHg})$ & $77.4 \pm 13.9$ & $82.9 \pm 14.2 *$ & $78.21 \pm 11.6$ & $79.3 \pm 14.3$ \\
\hline Total cholesterol (mmol/L) & $3.97 \pm 0.86$ & $4.11 \pm 0.91 *$ & $3.95 \pm 0.84$ & $4.35 \pm 1.17^{*}$ \\
\hline Triglycerides (mmol/L) & $1.08 \pm 0.23$ & $1.33 \pm 0.26^{*}$ & $0.94 \pm 0.22$ & $1.20 \pm 0.31 *$ \\
\hline LDL-C (mmol/L) & $2.21 \pm 0.36$ & $2.38 \pm 0.39 *$ & $2.17 \pm 0.33$ & $2.51 \pm 0.37 *$ \\
\hline HDL-C (mmol/L) & $1.13 \pm 0.25$ & $1.08 \pm 0.28$ & $1.27 \pm 0.27$ & $1.20 \pm 0.27$ \\
\hline Fasting glucose $(\mathrm{mmol} / \mathrm{L})$ & $4.96 \pm 0.33$ & $5.13 \pm 0.37 *$ & $4.87 \pm 0.33$ & $5.09 \pm 0.37 *$ \\
\hline Creatinine $(\mathrm{mmol} / \mathrm{L})$ & $80.4 \pm 15.4$ & $89.0 \pm 18.6^{*}$ & $66.9 \pm 12.8$ & $73.0 \pm 13.4^{*}$ \\
\hline Urea nitrogen $(\mathrm{mmol} / \mathrm{L})$ & $4.57 \pm 1.29$ & $4.92 \pm 1.47^{*}$ & $3.96 \pm 1.16$ & $4.47 \pm 1.27 *$ \\
\hline Uric acid $(\mu \mathrm{mol} / \mathrm{L})$ & $295.4 \pm 63.9$ & $460.9 \pm 45.4^{*}$ & $237.3 \pm 55.6$ & $396.4 \pm 42.1^{*}$ \\
\hline
\end{tabular}

Note: BMI, body mass index; WC, waist circumference; SBP, systolic blood pressure; DBP, diastolic blood pressure; LDL-C, low density lipoprotein cholesterol; HDL-C, high density lipoprotein cholesterol; ${ }^{*} P<0.05$ between the normouricemic controls and hyperuricemic subjects.

have significantly higher probability of suffering from hyperuricemia than the ones with $\mathrm{CT}$ and $\mathrm{CC}$ genotypes after adjustments for BMI, SBP, DBP, fasting glucose, total cholesterol, triglycerides, LDL-C and creatinine. The results of our study was consistent with the GWAS on serum urate concentrations [13], we found that the TT genotype of rs 2941484 in $H N F 4 G$ gene was associated with hyperuricemia only in Chinese male population. Some case-control studies have previously identified gene variants that are associated with gender-specific susceptibility to hyperuricemia [31,32], they both reported the gender-specific gene for hyperuricemia and gout in men rather than in women [33,34]. The sex specificity demonstrated in the present study was not clear yet. The possible reasons may be as follows: the dominant number of male hyperuricemia and gout patients over female ones, meanwhile, the female estrogen can promote the excretion of uric acid and inhibit the onset of arthritis. The two reasons above may make a large sample of female hyperuricemia patients difficult to collect, then the probability of discovering new genetic variants might be low. Therefore, the association between the genetic variants and hyperuricemia in men was much easier to be discovered.

The mechanism by which $H N F 4 G$ may be associated with hyperuricemia is still unclear. Many researchers have discovered the association of $H N F 4 G$ with obesity, since rising levels of obesity can contribute greatly to increasing prevalence of hyperuricemia and gout. We hypothesized that the association of $H N F 4 G$ with hyperuricemia may be established via its association with obesity. In this paper, we have also confirmed that BMI is significant risk factor for hyperuricemia in the logistic regression $(O R=2.912$, $P<0.001)$. Meanwhile, in a GWAS study including up to 263,407 European individuals [35], an SNP near HNF4G (rs4735692) was found to be associated with clinical classes of obesity. A gene knockout mice experiment found that the HNF4G knockout (HNF4 gamma (-/-)) mice had lowered energy expenditure and locomotor activity during night time that resulted in a higher body weight when compared with littermate wild-type mice (HNF4 gamma $(+/+))$ [36]. The increased probability of obesity caused by lowered energy expenditure and locomotor activity may subsequently increase the probability of hyperuricemia. In one large animal experiment, Ramayo-Caldas et al [37] found that HNF4G had the regulatory role in intramuscular fat deposition of beef cattle. Meanwhile, the intramuscular fat percentage and body adiposity have been proved to be the good predictors for the obesity status [38]. At the molecular level, one study suggested that the HNF4G may be transcription factors that are constitutively bound to fatty acids [39]. Since the plasma free fatty acid may be the reasons leading to obesity and insulin resistance, $H N F 4 G$ may be associated with hyperuricemia from its association with fatty acids levels.

The present study has the significant strength. First, the SNPs near $H N F 4 G$ was found to be associated with uric acid concentrations by GWAS based on large 
Table 2: Genotyping and allele distributions in control subjects and patients with hyperuricemia

\begin{tabular}{|c|c|c|c|c|c|c|}
\hline \multirow[b]{2}{*}{ Variants } & \multicolumn{3}{|c|}{ Men } & \multicolumn{3}{|c|}{ Women } \\
\hline & $\begin{array}{c}\text { Normouricemic } \\
\text { controls }\end{array}$ & $\begin{array}{c}\text { Hyperuricemic } \\
\text { subjects }\end{array}$ & $P$ value & $\begin{array}{c}\text { Normouricemic } \\
\text { controls }\end{array}$ & $\begin{array}{c}\text { Hyperuricemic } \\
\text { subjects }\end{array}$ & $P$ value \\
\hline \multicolumn{7}{|c|}{ rs2977939 (SNP1) } \\
\hline \multicolumn{7}{|c|}{ Genotyping } \\
\hline $\mathrm{TT}$ & $200(82.3 \%)$ & $204(81.6 \%)$ & & $135(82.8 \%)$ & $142(86.6 \%)$ & \\
\hline CT & $41(16.9 \%)$ & $43(17.2 \%)$ & & $27(16.6 \%)$ & $22(13.4 \%)$ & \\
\hline $\mathrm{CC}$ & $2(0.8 \%)$ & $3(1.2 \%)$ & 1.000 & $1(0.6 \%)$ & $0(0 \%)$ & 0.397 \\
\hline \multicolumn{7}{|c|}{ Dominant model } \\
\hline $\mathrm{TT}$ & $200(82.3 \%)$ & $204(81.6 \%)$ & & $135(82.8 \%)$ & $142(86.6 \%)$ & \\
\hline $\mathrm{CC}+\mathrm{CT}$ & $43(17.7 \%)$ & $46(18.4 \%)$ & 0.839 & $28(17.2 \%)$ & $22(13.4 \%)$ & 0.344 \\
\hline \multicolumn{7}{|c|}{ Recessive model } \\
\hline $\mathrm{CC}$ & $2(0.8 \%)$ & $3(1.2 \%)$ & & $1(0.6 \%)$ & $0(0 \%)$ & \\
\hline $\mathrm{TT}+\mathrm{CT}$ & $241(99.2 \%)$ & $247(98.8 \%)$ & 1.000 & $162(99.4 \%)$ & $164(100.0 \%)$ & 0.498 \\
\hline \multicolumn{7}{|l|}{ Allele } \\
\hline $\mathrm{C}$ & $45(9.3 \%)$ & $49(9.8 \%)$ & & $29(8.9 \%)$ & $22(6.7 \%)$ & \\
\hline $\mathrm{T}$ & $441(90.7 \%)$ & $451(90.2 \%)$ & 0.773 & $297(91.1 \%)$ & $306(93.3 \%)$ & 0.297 \\
\hline \multicolumn{7}{|c|}{ rs1805098 (SNP2) } \\
\hline \multicolumn{7}{|c|}{ Genotyping } \\
\hline $\mathrm{GG}$ & $80(32.8 \%)$ & $87(34.8 \%)$ & & $54(33.3 \%)$ & $58(35.4 \%)$ & \\
\hline $\mathrm{AG}$ & $122(50.0 \%)$ & $125(50.0 \%)$ & & $83(51.2 \%)$ & $87(53.0 \%)$ & \\
\hline $\mathrm{AA}$ & $42(17.2 \%)$ & $38(15.2 \%)$ & 0.796 & $25(15.4 \%)$ & $19(11.6 \%)$ & 0.594 \\
\hline \multicolumn{7}{|c|}{ Dominant model } \\
\hline $\mathrm{AG}$ & $122(50.0 \%)$ & $125(50.0 \%)$ & & $83(51.2 \%)$ & $87(53.0 \%)$ & \\
\hline $\mathrm{AA}+\mathrm{GG}$ & $122(50.0 \%)$ & $125(50.0 \%)$ & 1.000 & $79(48.8 \%)$ & $77(47.0 \%)$ & 0.743 \\
\hline \multicolumn{7}{|c|}{ Recessive model } \\
\hline $\mathrm{AA}$ & $42(17.2 \%)$ & $38(15.2 \%)$ & & $25(15.4 \%)$ & $19(11.6 \%)$ & \\
\hline $\mathrm{GG}+\mathrm{AG}$ & $202(82.8 \%)$ & $212(84.8 \%)$ & 0.544 & $137(84.6 \%)$ & $145(88.4 \%)$ & 0.309 \\
\hline \multicolumn{7}{|l|}{ Allele } \\
\hline A & $206(42.2 \%)$ & $201(40.2 \%)$ & & $133(41.0 \%)$ & $125(38.1 \%)$ & \\
\hline $\mathrm{G}$ & $282(57.8 \%)$ & $299(59.8 \%)$ & 0.520 & $191(59.0 \%)$ & $203(61.9 \%)$ & 0.443 \\
\hline \multicolumn{7}{|c|}{ rs2941484 (SNP3) } \\
\hline \multicolumn{7}{|c|}{ Genotyping } \\
\hline $\mathrm{CC}$ & $114(46.9 \%)$ & $108(43.2 \%)$ & & $77(47.2 \%)$ & $74(45.1 \%)$ & \\
\hline CT & $107(44.0 \%)$ & $100(40.0 \%)$ & & $72(44.2 \%)$ & $72(43.9 \%)$ & \\
\hline TT & $22(9.1 \%)$ & $42(16.8 \%)$ & $0.038 *$ & $14(8.6 \%)$ & $18(11.0 \%)$ & 0.757 \\
\hline \multicolumn{7}{|c|}{ Dominant model } \\
\hline $\mathrm{CC}$ & $114(46.9 \%)$ & $108(43.2 \%)$ & & $77(47.2 \%)$ & $74(45.1 \%)$ & \\
\hline $\mathrm{TT}+\mathrm{CT}$ & $129(53.1 \%)$ & $142(56.8 \%)$ & 0.407 & $86(52.8 \%)$ & $90(54.9 \%)$ & 0.701 \\
\hline \multicolumn{7}{|c|}{ Recessive model } \\
\hline $\mathrm{TT}$ & $22(9.1 \%)$ & $42(16.8 \%)$ & & $14(8.6 \%)$ & $18(11.0 \%)$ & \\
\hline $\mathrm{CC}+\mathrm{CT}$ & $221(90.9 \%)$ & $208(83.2 \%)$ & $0.011^{*}$ & $149(91.4 \%)$ & $146(89.0 \%)$ & 0.468 \\
\hline Allele & & & & & & \\
\hline $\mathrm{C}$ & $335(68.9 \%)$ & $316(63.2 \%)$ & & $226(69.3 \%)$ & $220(67.1 \%)$ & \\
\hline $\mathrm{T}$ & $151(31.1 \%)$ & $184(36.8 \%)$ & 0.058 & $100(30.7 \%)$ & $108(32.9 \%)$ & 0.536 \\
\hline rs4735692 (SI & & & & & & \\
\hline Genotypin & & & & & & \\
\hline $\mathrm{GG}$ & $94(38.7 \%)$ & $93(37.2 \%)$ & & $60(36.8 \%)$ & $66(40.2 \%)$ & \\
\hline $\mathrm{AG}$ & $108(44.4 \%)$ & $114(45.6 \%)$ & & $72(44.2 \%)$ & $73(44.5 \%)$ & \\
\hline $\mathrm{AA}$ & $41(16.9 \%)$ & $43(17.2 \%)$ & 0.944 & $31(19.0 \%)$ & $25(15.2 \%)$ & 0.627 \\
\hline Dominant mc & & & & & & \\
\hline $\mathrm{AG}$ & $108(44.4 \%)$ & $114(45.6 \%)$ & & $72(44.2 \%)$ & $73(44.5 \%)$ & \\
\hline $\mathrm{GG}+\mathrm{AA}$ & $135(55.6 \%)$ & $136(54.4 \%)$ & 0.797 & $91(55.8 \%)$ & $91(55.5 \%)$ & 0.951 \\
\hline Recessive mo & & & & & & \\
\hline AA & $41(16.9 \%)$ & $43(17.2 \%)$ & & $31(19.0 \%)$ & $25(15.2 \%)$ & \\
\hline $\mathrm{GG}+\mathrm{AG}$ & $202(83.1 \%)$ & $207(82.8 \%)$ & 0.923 & $132(81.0 \%)$ & $139(84.8 \%)$ & 0.365 \\
\hline Allele & & & & & & \\
\hline $\mathrm{G}$ & $296(60.9 \%)$ & $300(60.0 \%)$ & & $192(58.9 \%)$ & $205(62.5 \%)$ & \\
\hline A & $190(39.1 \%)$ & $200(40.0 \%)$ & 0.771 & $134(41.1 \%)$ & $123(37.5 \%)$ & 0.345 \\
\hline
\end{tabular}

Note: $* P<0.05$ between the normouricemic controls and hyperuricemic subjects. 
Table 3: Logistic regression analysis of confounding factors associated with hyperuricemia

\begin{tabular}{lccc}
\hline \multicolumn{1}{c}{ Risk factors } & Odd ratios & $\mathbf{9 5 \%}$ CI & $\boldsymbol{P}$ value \\
\hline TT genotype of rs2941484 & 2.170 & $1.348-2.992$ & $<0.001^{*}$ \\
BMI & 2.912 & $1.988-3.837$ & $<0.001^{*}$ \\
SBP & 1.149 & $0.867-1.431$ & 0.412 \\
DBP & 1.091 & $0.753-1.429$ & 0.766 \\
Fasting glucose & 2.798 & $1.983-3.613$ & $<0.001^{*}$ \\
Total cholesterol & 1.531 & $1.101-1.961$ & $0.029^{*}$ \\
Triglycerides & 1.133 & $0.780-1.636$ & 0.122 \\
LDL-C & 1.287 & $1.004-1.570$ & $0.047^{*}$ \\
Creatinine & 2.106 & $1.762-2.451$ & $<0.001^{*}$ \\
\hline
\end{tabular}

Note: BMI, body mass index; SBP, systolic blood pressure; DBP, diastolic blood pressure; LDL-C, low density lipoprotein cholesterol; $* P<0.05$ between the normouricemic controls and hyperuricemic subjects.

sample of European decedents, the confirmation of the results in Chinese Han population for the first time may contributed greatly to the in-depth studies of the gene. Second, all the hyperuricemia subjects and gender and age-matched normouricemic controls were selected based on the Cardiovascular Risk Survey (CRS) study, which is the representative sample of the general adult Han population in China. Thus, these genotyping results can be generalized to the full adult Han population aged above 35 years in China.

The limitation of this study is based on its crosssectional sample population, it can't reflect the causal relationship between the $H N F 4 G$ gene and hyperuricemia. Second, we did not include ethnic specified data in the paper since the prevalence of hyperuricemia in Uygur and Kazakh population was too low for a genetic association study. Third, the since the female hyperuricemia patients were difficult to collect, the detection power of discovering the new genetic variants may decrease in women.

In conclusion, this is first time that association between the human $H N F 4 G$ gene and hyperuricemia has been examined in the Chinese Han population. The present data indicates that TT genotype of rs2941484 in the human $H N F 4 G$ gene might be a gender-specific genetic marker for hyperuricemia in Chinese Han men.

\section{MATERIALS AND METHODS}

\section{Ethical approval of the study protocol}

Written informed consent was obtained from all participants. All participants explicitly provided permission for DNA analysis as well as collection of relevant clinical data. This study was approved by the Ethics Committee of the First Affiliated Hospital of Xinjiang Medical University (Urumqi, China). It was conducted according to the standards of the Declaration of Helsinki.

\section{Subjects}

All the hyperuricemia subjects and gender and age-matched normouricemic controls were selected from the Cardiovascular Risk Survey (CRS) study, the detailed description of the study population and the methods were described previously [40-42]. Briefly, the CRS study used a 4-stage stratified sampling method to select a representative sample of the general population in Xinjiang, northwest of China. The research sites included Urumqi City, Kelamayi City, Fukang City, Turpan Prefecture, Hetian Prefecture, Yili Prefecture. The time period was from October 2007 to March 2010. The selections made from sampling units were based on geographic area, sex, and age groups using household registries. In total, the CRS included 14618 participants (5757 Hans, 4767 Uygurs, and 4094 Kazakhs). In this present study, we only selected our subjects based on the Chinese Han population in Xinjiang.

In this study, hyperuricemia was defined as SUA $\geq 7 \mathrm{mg} / \mathrm{dl}(416 \mathrm{mmol} / \mathrm{L}$, male $)$ or $\mathrm{SUA} \geq 6 \mathrm{mg} / \mathrm{dl}(357$ $\mathrm{mmol} / \mathrm{L}$, female) [43-45]. The patients may have hypertension (The diagnosis of hypertension was established if patients were on antihypertensive medication or if the mean of 3 measurements of systolic blood pressure (SBP) $\geq 140 \mathrm{mmHg}$ or diastolic blood pressure (DBP) $\geq 90 \mathrm{mmHg}$, respectively), or diabetes mellitus (The diagnosis of diabetes mellitus was established if fasting plasma glucose $\geq 7.0 \mathrm{mmol} / \mathrm{L}$, or with a history or treatment of diabetes). In addition, individuals with history of lowering serum uric acid agents were excluded. All enrolled subjects should have the serum blood urea nitrogen, serum creatinine within the normal range, the normal range of serum blood urea nitrogen was 3.2-7.1 $\mathrm{mmol} / \mathrm{L}$ in both men and women, while the normal range of serum creatinine was $53-106 \mathrm{umol} / \mathrm{L}$ for men and $44-97 \mathrm{umol} / \mathrm{L}$ for women, respectively.

In total, we enrolled a total of 414 Han (250 male and 164 female) hyperuricemia patients. 406 Han 
(243 male and 163 female) gender and age-matched normouricemic subjects were enrolled as the controls. The age of enrolled patients ranged from 35 to 88 . The average uric acid was $379.32 \pm 54.52 \mu \mathrm{mol} / \mathrm{L}$ for men and $317.10 \pm 48.83 \mu \mathrm{mol} / \mathrm{L}$ for women.

\section{SNP selection}

$H N F 4 G$ gene in human is one of the two isoforms of human HNF4 gene (the other isoform being HNF4A). It consists of 408 amino acids and is located on chromosome $8 \mathrm{q} 21.11$. This gene consists approximately 26.88 kilobase pairs $(\mathrm{kbp})$ and contains ten exons, which are separated by nine introns.

There are 1354 SNPs of the human HNF4G gene listed in the National Center for Biotechnology Information SNP database (http://www.ncbi.nlm.nih. gov/SNP). In this study, we screened the data on the International HapMap Project website (http://hapmap.ncbi. nlm.nih.gov/index.html.en) for the Tag SNPs of HNF4G gene. SNPs with relatively high minor allele frequencies (MAF) have been shown to be useful as genetic markers in genetic association studies. In this condition, there were four SNPs (rs2977939, rs1805098, rs2941484, rs2941465), which had a MAF of $>0.1$ and r2 cutoff of 0.5 among Chinese Han in Beijing as the markers. All the four SNPs are located within or near the $H N F 4 G$ gene (Figure 1). However, we failed to find the the TaqMan SNP Genotyping Assays for rs2941465 at the Applied Biosystems (ABI) website (http://www.lifetechnologies. com/order/genome-database). We excluded rs2941465, which was tagged only by itself from our experiment. Meanwhile, rs4735692, which was found to be associated with clinical classes of obesity in GWAS were also included in the experiment [35]. (Figure 1)

We designated the four SNPs as SNP1 (rs2977939, C_26362437_10), SNP2 (rs1805098, C_2158198_20), SNP3 (rs2941484, C_15867636_10) and SNP4 (rs4735692, C_31080394_10), which were in order of increasing distance from the $5^{\prime}$ end of the gene (Figure 1).

\section{DNA extraction and laboratory methods}

Blood samples were obtained from an antecubital vein into EDTA tubes in the morning after an overnight fasting period. All the collected samples were transported on dry ice at prearranged intervals to Xinjiang Key Laboratory of Cardiovascular Disease Research. The genomic DNA was extracted from the peripheral blood leukocytes using phenol and chloroform extraction method [46]. The serum concentration of serum total cholesterol, triglyceride, low density lipoprotein (LDL),

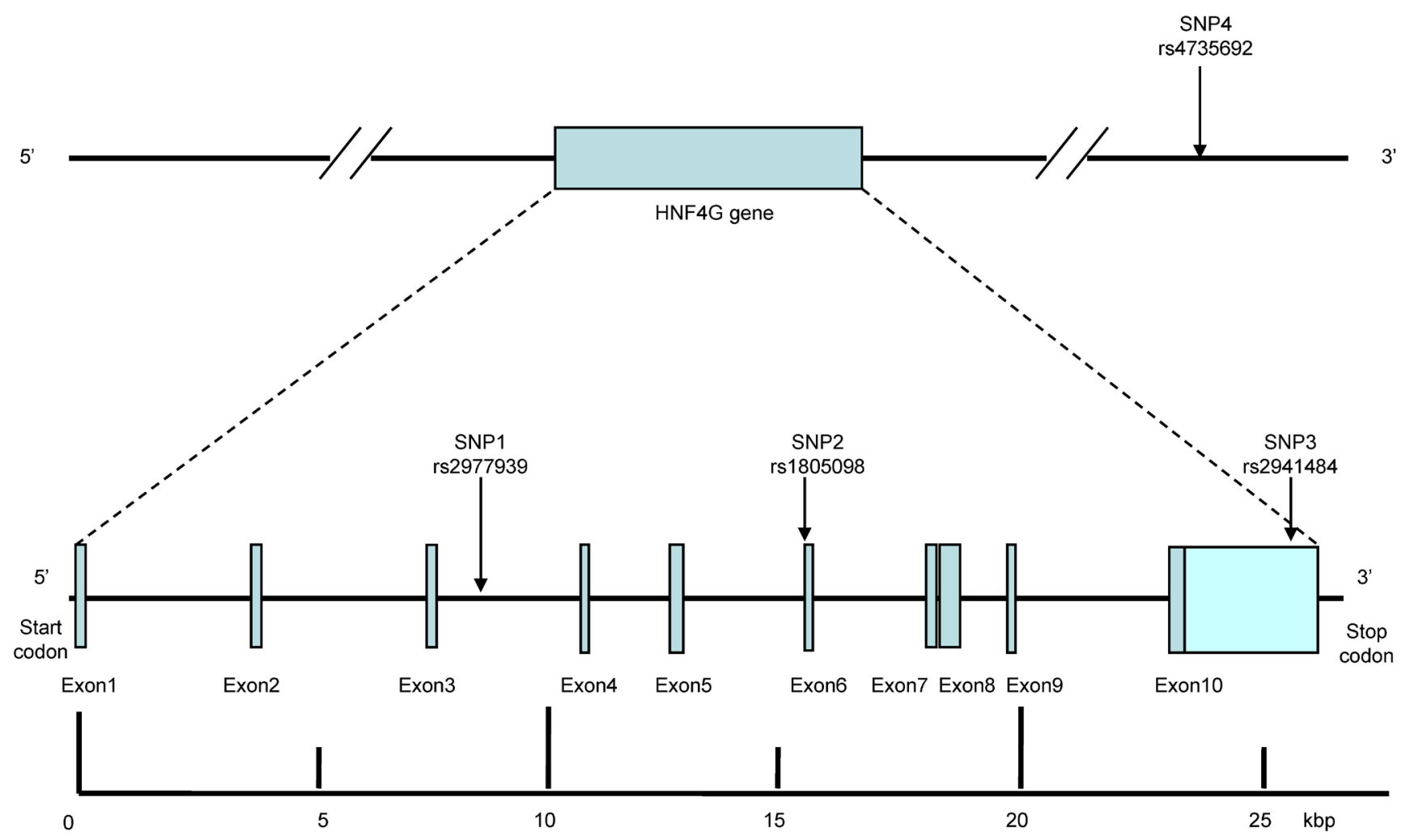

Figure 1: Structure of the human HNF4G gene. The gene consists of ten exons (boxes) separated by nine introns (lines; intergenic regions). Filled boxes indicate the coding regions, while arrows indicate the locations of single-nucleotide polymorphisms (SNPs). SNP1 is located in the introns area between the exon 3 and exon 4. SNP2 is located in the exon 6. SNP3 is located in the stop codon. SNP4 is located in downstream area of $H N F 4 G$ gene. kbp, kilobase pairs. 
high density lipoprotein (HDL) and fasting glucose were measured by the Clinical Laboratory Department of the First Affiliated Hospital of Xinjiang Medical University with the biochemical analyzer (Dimension AR/AV Clinical Chemistry System, Newark, NJ, USA) [47].

\section{Genotyping}

Genotyping was performed using the TaqMan SNP Genotyping Assay (Applied Biosystems). The primers and probes used in the TaqMan SNP Genotyping Assays (Applied Biosystems) were chosen based on information available at the ABI website (http://www.lifetechnologies. com/order/genome-database).

PCR amplification was performed using $2.5 \mu \mathrm{l}$ of TaqMan Universal Master Mix, No AmpErase UNG $(2 \times)$ (Applied Biosystems) in a $5 \mu \mathrm{l}$ final reaction volume, along with 2 ng DNA, $2.375 \mu$ l ultrapure water, $0.079 \mu \mathrm{l}$ Tris-EDTA (TE) buffer $(1 \times), 0.046 \mu$ l TaqMan SNP Genotyping Assay Mix (40×) containing a $331.2 \mathrm{nmol} / 1$ final concentration of primers and a $73.6 \mathrm{nmol} / \mathrm{l}$ final concentration of the probes. The thermal cycling conditions were as follows: $50^{\circ} \mathrm{C}$ for $2 \mathrm{~min} ; 95^{\circ} \mathrm{C}$ for 10 min; 50 cycles of $95^{\circ} \mathrm{C}$ for $15 \mathrm{~s}$; and $60^{\circ} \mathrm{C}$ for $1 \mathrm{~min}$ [48].

Each 96-well plate contained 80 DNA samples of an unknown genotype and four reaction mixtures containing reagents but no DNA (control). The control samples without DNA are a necessary part of the sequence detection system of 7900 signal processing system, as outlined in the TaqMan Allelic Discrimination Guide (Applied Biosystems). The plates were read on the sequence detection system 7900 instrument with the end-point analysis mode of the sequence detection system version 1.6.3 software package (Applied Biosystems). The genotypes were determined visually based on the dyecomponent fluorescent emission data depicted in the X-Y scatter-plot of the sequence detection system software. The genotypes were also determined automatically by the signal processing algorithms of the software. The results of each scoring method were saved in two separate output files for later comparison.

\section{Statistical analysis}

Statistical analyses were performed using SPSS software for Windows, version 17.0 (SPSS, Chicago, IL). All continuous variables were expressed as mean \pm s.d. Differences in continuous variables between the hyperuricemia patients and normouricemic control subjects were analyzed using Mann-Whitney $U$-test. Differences in categorical variables between the hyperuricemia patients and normouricemic control subjects were analyzed using the chi square or Fisher's exact test. Differences in distributions of genotypes and alleles were analyzed using Fisher's exact test. Statistical significance was established at $P<0.05$.

\section{CONFLICTS OF INTEREST}

The authors declare no potential conflicts of interests.

\section{GRANT SUPPORT}

This study was supported by grants from the Xinjiang Science and Technology Support Project (Grant No. 2016E02073), National Natural Science Foundation of China (Grant No. 81560071), and Innovation Team Development Project of Ministry of Education of China (IRT13094).

\section{REFERENCES}

1. Krishnan E. Interaction of inflammation, hyperuricemia, and the prevalence of hypertension among adults free of metabolic syndrome: NHANES 2009-2010. J Am Heart Assoc. 2014; 3:e000157.

2. Yu S, Yang H, Guo X, Zhang X, Zhou Y, Ou Q, Zheng L, Sun Y. Prevalence of hyperuricemia and its correlates in rural Northeast Chinese population: from lifestyle risk factors to metabolic comorbidities. Clin Rheumatol. 2016; 35:1207-15.

3. Zhu Y, Pandya BJ, Choi HK. Prevalence of gout and hyperuricemia in the US general population: the National Health and Nutrition Examination Survey 2007-2008. Arthritis Rheum. 2011; 63:3136-41.

4. Liu R, Han C, Wu D, Xia X, Gu J, Guan H, Shan Z, Teng W. Prevalence of Hyperuricemia and Gout in Mainland China from 2000 to 2014: A Systematic Review and MetaAnalysis. Biomed Res Int. 2015; 2015:762820.

5. Villegas R, Xiang YB, Elasy T, Xu WH, Cai H, Cai Q, Linton MF, Fazio S, Zheng W, Shu XO. Purine-rich foods, protein intake, and the prevalence of hyperuricemia: the Shanghai Men's Health Study. Nutr Metab Cardiovasc Dis. 2012; 22:409-16.

6. Arromdee E, Michet CJ, Crowson CS, O'Fallon WM, Gabriel SE. Epidemiology of gout: is the incidence rising? J Rheumatol. 2002; 29:2403-6.

7. Singh JA. Quality of life and quality of care for patients with gout. Curr Rheumatol Rep. 2009; 11:154-60.

8. Wallace KL, Riedel AA, Joseph-Ridge N, Wortmann R. Increasing prevalence of gout and hyperuricemia over 10 years among older adults in a managed care population. J Rheumatol. 2004; 31:1582-7.

9. Yoo HG, Lee SI, Chae HJ, Park SJ, Lee YC, Yoo WH. Prevalence of insulin resistance and metabolic syndrome in patients with gouty arthritis. Rheumatol Int. 2011; 31:485-91.

10. Nath SD, Voruganti VS, Arar NH, Thameem F, LopezAlvarenga JC, Bauer R, Blangero J, MacCluer JW, Comuzzie AG, Abboud HE. Genome scan for determinants of serum uric acid variability. J Am Soc Nephrol. 2007; 18:3156-63. 
11. Yang Q, Guo CY, Cupples LA, Levy D, Wilson PW, Fox CS. Genome-wide search for genes affecting serum uric acid levels: the Framingham Heart Study. Metabolism. $2005 ; 54: 1435-41$.

12. Scharpf RB, Mireles L, Yang Q, Köttgen A, Ruczinski I, Susztak K, Halper-Stromberg E, Tin A, Cristiano S, Chakravarti A, Boerwinkle E, Fox CS, Coresh J, et al. Copy number polymorphisms near SLC2A9 are associated with serum uric acid concentrations. BMC Genet. 2014; 15:81.

13. Köttgen A, Albrecht E, Teumer A, Vitart V, Krumsiek J, Hundertmark C, Pistis G, Ruggiero D, O’Seaghdha CM, Haller T, Yang Q, Tanaka T, Johnson AD, et al. Genome-wide association analyses identify 18 new loci associated with serum urate concentrations. Nat Genet. 2013; 45:145-54.

14. Drewes T, Senkel S, Holewa B, Ryffel GU. Human hepatocyte nuclear factor 4 isoforms are encoded by distinct and differentially expressed genes. Mol Cell Biol. 1996; 16:925-31.

15. Sladek FM, Zhong WM, Lai E, Darnell JE Jr. Liverenriched transcription factor HNF-4 is a novel member of the steroid hormone receptor superfamily. Genes Dev. 1990; 4:2353-65.

16. Sladek FM. Orphan receptor HNF-4 and liver-specific gene expression. Receptor. 1994; 4:64.

17. Lanaspa MA, Tapia E, Soto V, Sautin Y, SánchezLozada LG. Uric acid and fructose: potential biological mechanisms. Semin Nephrol. 2011; 31:426-32.

18. Tapia E, Cristóbal M, García-Arroyo FE, Soto V, MonroySánchez F, Pacheco U, Lanaspa MA, Roncal-Jiménez CA, Cruz-Robles D, Ishimoto T, Madero M, Johnson RJ, Sánchez-Lozada LG. Synergistic effect of uricase blockade plus physiological amounts of fructose-glucose on glomerular hypertension and oxidative stress in rats. Am J Physiol Renal Physiol. 2013; 304:F727-36.

19. Aroor AR, Mandavia CH, Sowers JR. Insulin resistance and heart failure: molecular mechanisms. Heart Fail Clin. 2012; 8:609-17.

20. Jalal DI, Chonchol M, Chen W, Targher G. Uric acid as a target of therapy in CKD. Am J Kidney Dis. 2013; 61:134- 46.

21. Sowers JR, Whaley-Connell A, Hayden MR. The role of overweight and obesity in the cardiorenal syndrome. Cardiorenal Med. 2011; 1:5-12.

22. Reed DR, Price RA. X-linkage does not account for the absence of father-son similarity in plasma uric acid concentrations. Am J Med Genet. 2000; 92:142-6.

23. Emmerson BT, Nagel SL, Duffy DL, Martin NG. Genetic control of the renal clearance of urate: a study of twins. Ann Rheum Dis. 1992; 51:375-7.

24. Wilk JB, Djousse L, Borecki I, Atwood LD, Hunt SC, Rich SS, Eckfeldt JH, Arnett DK, Rao DC, Myers RH. Segregation analysis of serum uric acid in the NHLBI Family Heart Study. Hum Genet. 2000; 106:355-9.

25. Naka H, Brownlee GG. Transcriptional regulation of the human factor IX promoter by the orphan receptor superfamily factor, HNF4, ARP1 and COUP/Ear3. Br J Haematol. 1996; 92:231-40.

26. Garrison WD, Battle MA, Yang C, Kaestner KH, Sladek FM, Duncan SA. Hepatocyte nuclear factor 4alpha is essential for embryonic development of the mouse colon. Gastroenterology. 2006; 130:1207-20.

27. Hertz R, Magenheim J, Berman I, Bar-Tana J. Fatty acyl$\mathrm{CoA}$ thioesters are ligands of hepatic nuclear factor-4alpha. Nature. 1998; 392:512-6.

28. Archer A, Sauvaget D, Chauffeton V, Bouchet PE, Chambaz J, Pinçon-Raymond M, Cardot P, Ribeiro A, Lacasa M. Intestinal apolipoprotein A-IV gene transcription is controlled by two hormone-responsive elements: a role for hepatic nuclear factor-4 isoforms. Mol Endocrinol. 2005; 19:2320-34.

29. Ozeki T, Takahashi Y, Kume T, Nakayama K, Yokoi T, Nunoya K, Hara A, Kamataki T. Co-operative regulation of the transcription of human dihydrodiol dehydrogenase (DD)4/aldo-keto reductase (AKR)1C4 gene by hepatocyte nuclear factor (HNF)-4alpha/gamma and HNF-1alpha. Biochem J. 2001; 355:537-44.

30. Ozeki T, Takahashi Y, Nakayama K, Kamataki T. Hepatocyte nuclear factor (HNF)-4 alpha/gamma, HNF1 alpha, and vHNF-1 regulate the cell-specific expression of the human dihydrodiol dehydrogenase (DD)4/AKR1C4 gene. Arch Biochem Biophys. 2002; 405:185-90.

31. Hong YS, Lee MJ, Kim KH, Lee SH, Lee YH, Kim BG, Jeong B, Yoon HR, Nishio H, Kim JY. The C677 mutation in methylene tetrahydrofolate reductase gene: correlation with uric acid and cardiovascular risk factors in elderly Korean men. J Korean Med Sci. 2004; 19:209-13.

32. Zhou D, Liu Y, Zhang X, Gu X, Wang H, Luo X, Zhang J, Zou H, Guan M. Functional polymorphisms of the ABCG2 gene are associated with gout disease in the Chinese Han male population. Int J Mol Sci. 2014; 15:9149-59.

33. Wu J, Qiu L, Guo XZ, Xu T, Cheng XQ, Zhang L, Li PC, Di Q, Wang Q, Ni L, Zhu GJ. Apolipoprotein e gene polymorphisms are associated with primary hyperuricemia in a chinese population. PLoS One. 2014; 9:e110864.

34. Zhang L, Spencer KL, Voruganti VS, Jorgensen NW, Fornage M, Best LG, Brown-Gentry KD, Cole SA, Crawford DC, Deelman E, Franceschini N, Gaffo AL, Glenn KR, et al. Association of functional polymorphism rs2231142 (Q141K) in the ABCG2 gene with serum uric acid and gout in 4 US populations: the PAGE Study. Am J Epidemiol. 2013; 177:923-32.

35. Berndt SI, Gustafsson S, Mägi R, Ganna A, Wheeler E, Feitosa MF, Justice AE, Monda KL, Croteau-Chonka DC, Day FR, Esko T, Fall T, Ferreira T, et al. Genome-wide meta-analysis identifies 11 new loci for anthropometric traits and provides insights into genetic architecture. Nat Genet. 2013; 45:501-12.

36. Gerdin AK, Surve VV, Jönsson M, Bjursell M, Björkman M, Edenro A, Schuelke M, Saad A, Bjurström S, Lundgren EJ, Snaith M, Fransson-Steen R, Törnell J, et al. Phenotypic 
screening of hepatocyte nuclear factor (HNF) 4-gamma receptor knockout mice. Biochem Biophys Res Commun. 2006; 349:825-32.

37. Ramayo-Caldas $\mathrm{Y}$, Fortes MR, Hudson NJ, PortoNeto LR, Bolormaa S, Barendse W, Kelly M, Moore SS, Goddard ME, Lehnert SA, Reverter A. A marker-derived gene network reveals the regulatory role of PPARGC1A, HNF4G, and FOXP3 in intramuscular fat deposition of beef cattle. J Anim Sci. 2014; 92:2832-45.

38. Bergman RN, Stefanovski D, Buchanan TA, Sumner AE, Reynolds JC, Sebring NG, Xiang AH, Watanabe RM. A better index of body adiposity. Obesity (Silver Spring). 2011; 19:1083-9.

39. Wisely GB, Miller AB, Davis RG, Thornquest AD Jr, Johnson R, Spitzer T, Sefler A, Shearer B, Moore JT, Miller AB, Willson TM, Williams SP. Hepatocyte nuclear factor 4 is a transcription factor that constitutively binds fatty acids. Structure. 2002; 10:1225-34.

40. Zheng YY, Xie X, Ma YT, Fu ZY, Ma X, Yang YN, Li XM, Pan S, Adi D, Chen BD, Liu F. Association of C5L2 genetic polymorphisms with coronary artery disease in a Han population in Xinjiang, China. Oncotarget. 2017; 8:8590 8596. doi: 10.18632/oncotarget.14353.

41. Chen BD, Yang YN, Ma YT, Pan S, He CH, Liu F, Ma X, Fu ZY, Li XM, Xie X, Zheng YY. Waist-to-Height Ratio and Triglycerides/High-Density Lipoprotein Cholesterol Were the Optimal Predictors of Metabolic Syndrome in Uighur Men and Women in Xinjiang, China. Metab Syndr Relat Disord. 2015; 13:214-20.

42. Chen BD, He CH, Ma YT, Yang YN, Liu F, Pan S, Ma X, Li XM, Fu ZY, Xie X, Zheng YY. Best anthropometric and atherogenic predictors of metabolic syndrome in the Chinese Han population in Xinjiang: the Cardiovascular Risk Survey. Ann Nutr Metab. 2014; 65:280-8.
43. Becker MA, Schumacher HR Jr, Wortmann RL, MacDonald PA, Eustace D, Palo WA, Streit J, JosephRidge N. Febuxostat compared with allopurinol in patients with hyperuricemia and gout. N Engl J Med. 2005; 353:2450-61.

44. Nagahama K, Inoue T, Iseki K, Touma T, Kinjo K, Ohya Y, Takishita S. Hyperuricemia as a predictor of hypertension in a screened cohort in Okinawa, Japan. Hypertens Res. 2004; $27: 835-41$.

45. Zhang W, Doherty M, Bardin T, Pascual E, Barskova V, Conaghan P, Gerster J, Jacobs J, Leeb B, Lioté F, McCarthy G, Netter P, Nuki G, et al. EULAR evidence based recommendations for gout. Part II: Management. Report of a task force of the EULAR Standing Committee for International Clinical Studies Including Therapeutics (ESCISIT). Ann Rheum Dis. 2006; 65:1312-24.

46. Adi D, Xie X, Ma YT1, Fu ZY, Yang YN, Li XM, Xiang Y, Liu F, Chen BD. Association of COL4A1 genetic polymorphisms with coronary artery disease in Uygur population in Xinjiang, China. Lipids Health Dis. 2013; 25;12:153.

47. Yuan Q, Fu Z, Wei J, Li PS, Miao HH, Qu YX, Xu J, Qin J, Li BL, Song BL, Ma Y. Identification and characterization of NPC1L1 variants in Uygur and Kazakh with extreme low-density lipoprotein cholesterol. Biochem Biophys Res Commun. 2016; 479:628-35.

48. Yuan Q, Xie X, Fu Z, Ma X, Yang Y, Huang D, Liu F, Dai C, Ma Y. Association of the histone-lysine N-methyltransferase MLL5 gene with coronary artery disease in Chinese Han people. Meta Gene. 2014; 2:514-24. 